\title{
7 甲状腺原発の悪性リンパ腫について
}

\author{
宮川信・千賀脩・岩浅武彦 \\ 牧内正夫 ・降旗力男 \\ （信州大学 第 2 外科）
}

甲状腺に原発する悪性腫痬の大部分は癌であり、 悪性リンパ腫の発生はまれである。われわれの教 室で、1953 から1977年までの25年間に取り扱っ た甲状腺悪性腫痬 (初回治療例) は 64.4 例で、そ のうち甲状腺原発と思われる悪性リンパ腫は 7 例 ( $1 \%$ )である。

その臨床像については表に示すごとく、年齢は 46 歳から71歳までで、他の悪性リンパ腫にみられ る若年発症例はない。性別は男性 3 例、女性 4 例 で男女差はほとんどない。治療についてみると、 5 例に根治手術が行なわれており、残りの 2 例の うち、症例 3 は71歳の高齢と脳卒中の既往と糖尿 病の合併を認めたため試験切除にとどめ放射線療 法と化学療法を行った。症例 6 は術中迅速診断で 慢性甲状腺资の診断がくだされ、手術の試験切除 にとどめた症例である。しかし、その後の永久標 本で悪性リンパ腫と判明したもので、放射線療法 と化学療法を行っている。予後は、表の示すごと く、 7 例中 3 例が生存している。これらの症例の 如く、きわめて急速な転移をきたし死の転帰をと るものと、長期生存の得られるものまで多彩な臨 床経過を示している。したがって病因論的に多く の問題が含まれている。すなわち、単発性の悪性 リンパ腫か、または多中心性発生の悪性リンパ腫 症の一環として甲状腺に発生したものかについて の検討が必要である。また、悪性リンパ腫の組織 診断は未分化癌、特に小細胞癌、あるいは慢性甲 状腺资との鑑別がしばしば困難で、特殊染色下に おいても鑑別困難な場合がある。これらの 7 例の 臨床像をまとめてみると以下のごとくになる。

まとめ 1. 甲状腺原発の悪性リンパ腫は、遠 隔転移のない時期に手術と放射線療法を併用すれ ば、予後は比較的良好である。2. 遠隔転移は 腹部臓器 (ことに消化器 ) に転移をきたすことが
多い。このような場合には化学療法を試みるべき である。 3. 甲状腺の悪性リンパ腫と小細胞癌 との鑑別はときに困難である。一般に悪性りンパ 腫の方が小細胞癌より予後良好であり、両者の鑑 別は予後を知るのでも必要である。

甲状腺原発の悪性リンパ腫

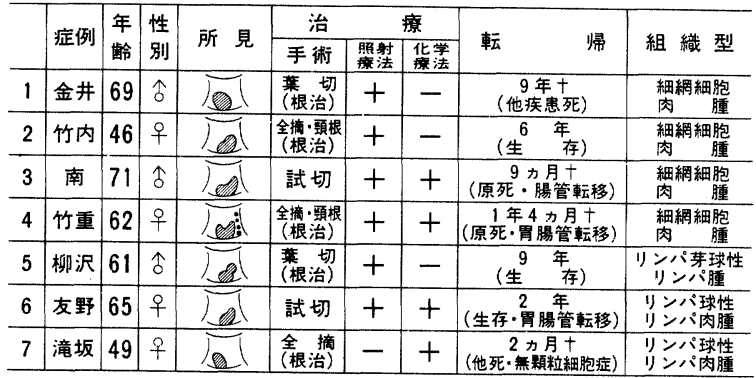

啠問 (千葉県がんセンター嶋田)

1） 72 歳女性。全経過 2 ケ月で死亡した一例を 追加した。

2) 針生検で診断をつけたが、試切などの時期は いつがよいか。

3 ）甲状腺疾患と鑑別のむずかしかった悪性リン パ腫の経験は如何か。

回答

我々のところでは針生検で診断をつけたことは ありません。頸部リンパ節に発生した悪性リンパ 腫は18例経験し、それが甲状腺へ波及した症例は 2 例経験しています。

\section{質問 （愛知医大一外小池）}

甲状腺原発悪性リンパ腫の先生の治療方針は手 術と放射線治療法と理解させていただいてよろし 
いでしょうか。また化学療法はどのようにされて いますか。

回答

ほぼ完全な手術が行なわれ、放射線照射を行っ た症例は、Follow up をとりながら経過を観察し その都度 ${ }^{67} \mathrm{Ga} \mathrm{Sca} n$ 、リンパ管造影、胸部X線な どから再燃を疑がわれたら、期を失せず化学療法 をとっている。

座長のをとめ （九州がんセンター 松村）

1. 㴗性リンパ腫の診断と治療は nodal と extranodal とでも違うが, 組織像と Stage を勘案し, 内科医 (造血器専門医), 放射線医, 外科医と病 理卸断医の総合的判断でなされ進められるべきで ありましょう。

2. 頭頸部領或に発生する症例が多いこと、試切 する際、充分な大きさの材料を挫隇したり圧迫を 加えないで婇取する工夫をすべきである(病理診 断を正確にするため)。

3. 多中心性発生は少く転移形成が早く、多発性 に発育する症例が多いためそのようにとられるも
質問

甲状腺の悪性リンパ腫が疑われる場合、試切は どの位の大きさの組織を採取されるのか御教示お 願いします。

回答

比較的大きな皮切で、反対側の甲状腺をも採取 して、スタンプを作りその診断を行って、次に永 久標本を作製し診断を下す。

のがあると考えられる。

今までとかくなおざりにされがちであった悪性 リンパ腫についての研究が本学会員によりさらに 充実し発展することを期待して本群を終ります。 